\title{
Comparative study of intravenous and topical administration of mesenchymal stem cells in experimental colitis
}

\author{
Didia Bismara Cury ${ }^{1,2 *}$, Rogério Antonio de Oliveira ${ }^{3}$, Maria Aparecida Dalboni ${ }^{1}$, Luciana Aparecida Reis ${ }^{1}$, Clara Vesolato ${ }^{1}$, Edson Pereira ${ }^{1}$ \\ and Nestor Schor ${ }^{1}$ \\ ${ }^{1}$ Department of Nephrology, Federal University of São Paulo ( UNIFESP), São Paulo, SP, Brazil \\ ${ }^{2}$ Department of Inflammatory Bowel Disease, Scope Clinical Center, Campo Grande, MS, Brazil \\ ${ }^{3}$ Department of Biostatistics, State University of São Paulo Júlio de Mesquita Filho (UNESP/IBB), Botucatu, SP, Brazil
}

\begin{abstract}
Adult marrow-derived mesenchymal stem cells (MSCs) have anti-inflammatory properties in patients with Inflammatory Bowel Disease (IBD), but systemic delivery is associated with safety concerns. Whether topical delivery of MSCs would provide similar efficacy to systemic administration is unknown. To compare topicallydelivered MSCs to systemic asministration, and non-MSC therapy, in animal model of colitis. Trinitrobenzenesulfonic acid (TNBS) colitis was induced in Wistar rats. Topical MSCs were compared to intravenous MSCs, adalimumab, infliximab and control in this model. Serial measurements of clinical criteria were used (i.e., weight, stool characteristics), and serum interleukin 6 (IL-6) and TNF measurements and macroscopic and microscopic scores were used to evaluate treatment efficacy. Topical and intravenous stem cell treatments, significantly prevented weight loss in TNBS mice on day 3 of colitis. There was greater evidence of a difference mainly on the third day $(\mathrm{p}<0.001)$. IV or PR stem cells also reduced serum IL-6 and TNF levels to similar levels to those of anti-TNF treated animals. In the intestinal tract, stem-cell treatment ameliorated the microscopic and macroscopic damage caused by TNBS. Rectal-delivered stem cells produced similar results to IV-delivered cells. This study demonstrates that rectal stem cells can treat colitis in an animal model to a similar extent to IV stem cells and systemic anti-TNF therapies. The mechanisms of this effect warrants further study.
\end{abstract}

\section{Introduction}

Inflammatory bowel diseases have pathophysiologies based on genetic inheritance associated with environmental factors related either to the intestinal lumen or not, and produce an exacerbated inflammatory response, resulting in intestinal or extraintestinal clinical manifestations [1-4].

In recent years, experimental models have significantly contributed to the understanding of these diseases, allowing the development of drugs with high specificity that act directly on target inflammatory mediators, such as Tumor Necrosis Factor alpha (TNF-alpha) and adhesion molecules, among others.This advancement has enabled treatment providers to change the natural history of these diseases, increasing the quality of life of affected patients and decreasing hospitalization and surgical intervention rates [5]. Although these drugs have modified the treatment scenario, primary drug failure due to loss of response has been observed over the years [6]. Primary failure has corresponded to more than $40 \%$ of cases [7], and serial clinical studies indicate a primary failure rate of 10 to $20 \%$. During one year, this loss of response may vary between 23 to $43 \%$ of cases [6]. Genetic factors, disease duration, smoking and even the production of antidrug antibodies have been associated with primary failure $[6,8]$.

Conversely, recent studies indicate the possibility of treatment using an immune path (cell therapy) different from drug therapy in patients who are intolerant to conventional drug treatments or when such treatments fail [9].
Cell therapy could represent the optimization of intestinal factors produced by mesenchymal stem cells, which have demonstrated the capacity to inhibit TNF-alpha and Interleukin 6 (IL-6) by regulating the incorrectly exacerbated immune response and inducing intestinal homeostasis, producing an important clinical response for healing the colonic mucosa in both experimental models and humans [9-11]. One of the limiting factors of this treatment is associated with opportunistic infections and uncontrolled cell development, which lead to neoplasms $[12,13]$. In addition to these data, these cells have the capacity to migrate to the lesion site, even when applied far from the lesion $[1,14]$.

Such lines of evidence have encouraged the studies regarding the topical application of these cells in the colon, which has potential as a new drug strategy and may decrease the side effects of this therapy [1].

\section{Objectives}

This study aims to assess the applicability and the results of mesenchymal stem cell implantation in animals submitted to

Correspondence to: Didia Bismara Cury, Director, Center of Inflammatory Bowel Disease, Clínica Scope, Campo Grande, MS 79002212, Brazil, Tel: +55673-3256040 Fax:+55-673-3256040; E-mail: didia_cury@uol.com.br

Key words: topical stem cell, intravenous stem cell, adalimumab, infliximab, colitis model

Received: January 03, 2016; Accepted: January 20, 2016; Published: January 23, 2016 
experimental colitis and to compare the effects of stem cells in animals treated with Infliximab and Adalimumab.

\section{Material and methods}

Experimental lesions were produced by trinitrobenzenesulfonic acid (TNBS) in male Wistar rats weighing approximately $250 \mathrm{~g}$ according to Morris [15]. The animals were evaluated before the TNBS lesions were created and again 24 hours after TNBS administration. This study was composed of six distinct groups, $\mathrm{n}=30$ animals. Group 1 (saline solution only), 2 (TNBS), 3 (TNBS+ Adalimumab), 4 (TNBS + Infliximab), 5 (TNBS + Tail Stem Cell) and 6 (TNBS + Rectum Stem Cell). All groups followed the same evaluation method, in which blood samples were collected for assessment of IL6 and TNF levels in the control groups (TNBS) and (saline only) one hour after, and in the therapy groups 24 hours after, TNBS damage. The animals were submitted to either cellular therapy or anti-TNFs, and one hour after that, blood samples were collected. The serum scores of these inflammatory markers (IL6 and TNF alfa), were taken with the Anti-TNF alfa rat set Elisa (BD Pharmigen) and IL6 rat set Elisa (BD Pharmigen) and plasmatic levels were taken according to the manufacturer's instructions. Clinical criteria, such as animal weight and stool characteristics, were simultaneously applied. On the fourth day, the animals were euthanized, and macroscopic and microscopic scores were recorded. The scores followed standards defined by Yugo e col [16].

The stem cells were obtained following the model by Reis et al. [17]. The statistical analyses were performed using analysis of variance (ANOVA) and Tukey's test to evaluate the differences observed at different periods for all treatments. Statistical significance was considered to be $\mathrm{p}<0.05$. All of the statistical analyses and graphics were produced in Minitab ${ }^{\circ}$ 16.1.1 (MINITAB ${ }^{\circ}$ is a trademark of Minitab Inc.).

\section{Results}

The model of experimental TNBS colitis has its efficacy confirmed when compared to the cotrol group (saline only). We could observe that the animals that were submitted to experimental TNBS colitis significantly lost weight, presented higher levels of IL6 and TNF alfa, as well as higher macroscopic and microscopic scores when compared to the Saline Solution Only control group $(\mathrm{p}<0.01)$.

The animals that were subjected to TNBS alone sequentially presented significantly lower weight when compared to the groups treated with anti-TNFs, an observation that was more evident on the third experiment day $(\mathrm{p}<0.005)$, demonstrating the efficacy of the treatment (Figure 1). In both the topical and intravenous stem cell groups, there was greater evidence of this difference, mainly on the third day $(p<0.001)$. Regarding stool characteristics, the TNBS group had diarrhea until the fourth day, in contrast with all groups that received treatment (Figure 1). In terms of inflammatory mediators, higher levels of TNF and IL6 were detected in the TNBS group (control) compared with the anti-TNF or stem cell groups, and significant differences could be observed with Adalimumab $(\mathrm{p}=0.024)$, Infliximab $(\mathrm{p}<0.01)$, and intravenous and topical stem cell treatment $(\mathrm{p}<0.001)$ (see Figures 2 and 3). Macroscopically, the TNBS group obtained the highest scores compared with the groups treated with anti-TNFs and between the stem cell groups $(\mathrm{p}<0.001)$ (Figure 4). Microscopically, a significant difference was detected $(\mathrm{p}<0.001)$ when the TNBS group was compared with the anti-TNF and stem cell groups (Figure 5).

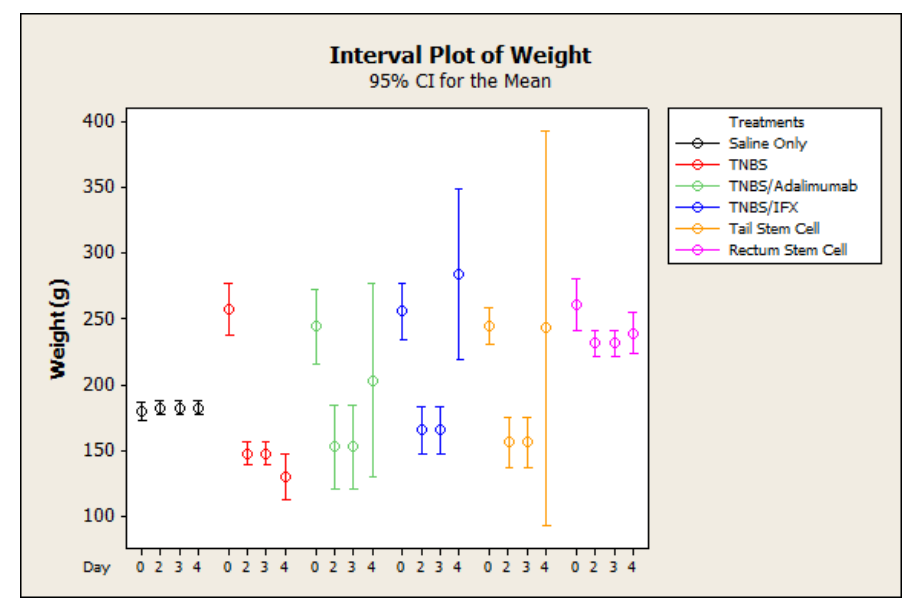

Figure 1. Average in body weight over time after induction of colitis with TNBS with different therapies $(\mathrm{p}<0.005)$.

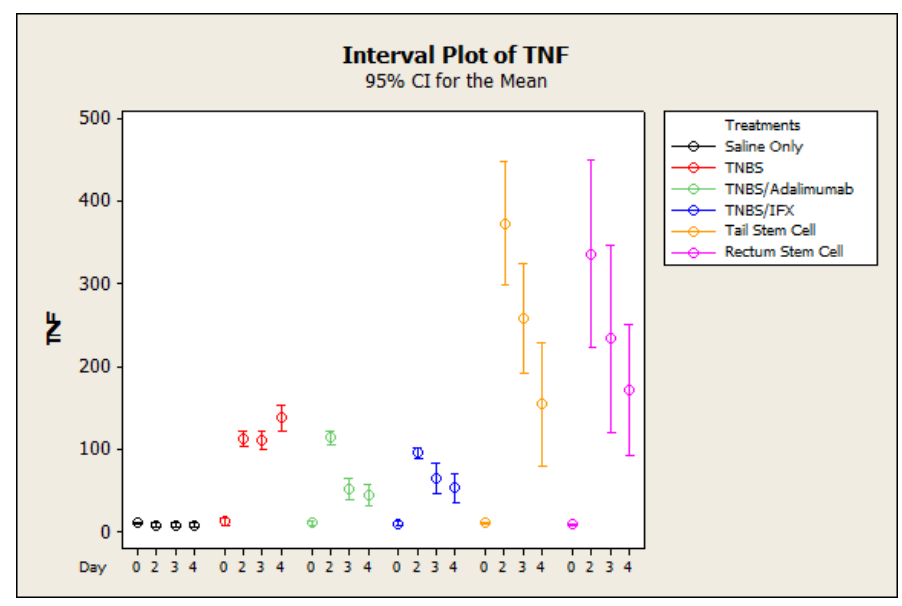

Figure 2. Mean Average blood serum TNF after induction of colitis with TNBS between treatment groups $(\mathrm{p}<0.001)$.

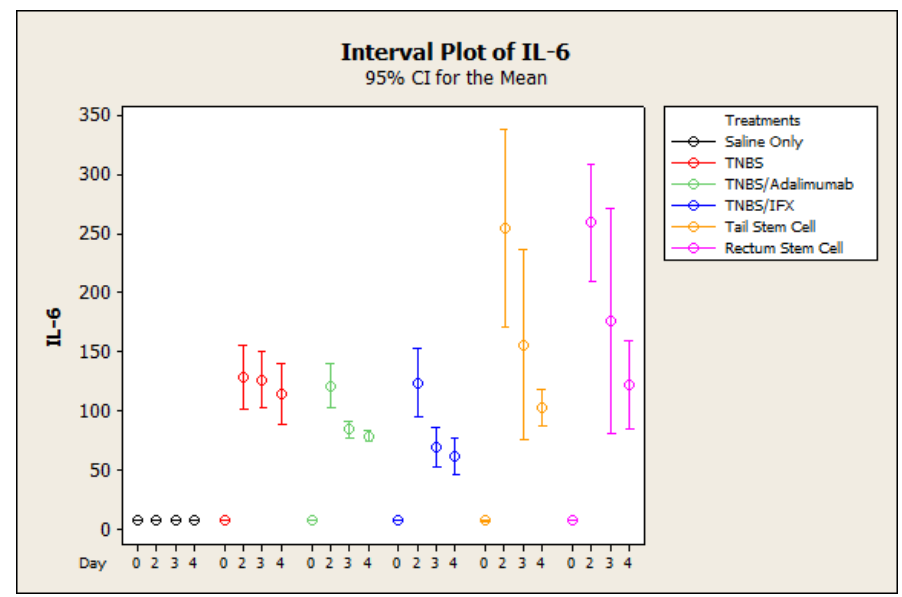

Figure 3. Mean Average blood serum IL6 after induction of colitis with TNBS between treatment groups $(\mathrm{p}<0.001)$.

\section{Discussions}

The present study is unprecedented, as applied in Wistar animals, and compares the effect of mesenchymal stem cells applied via enema and intravenous with other already known therapies, such as anti-TNFs [18]. 


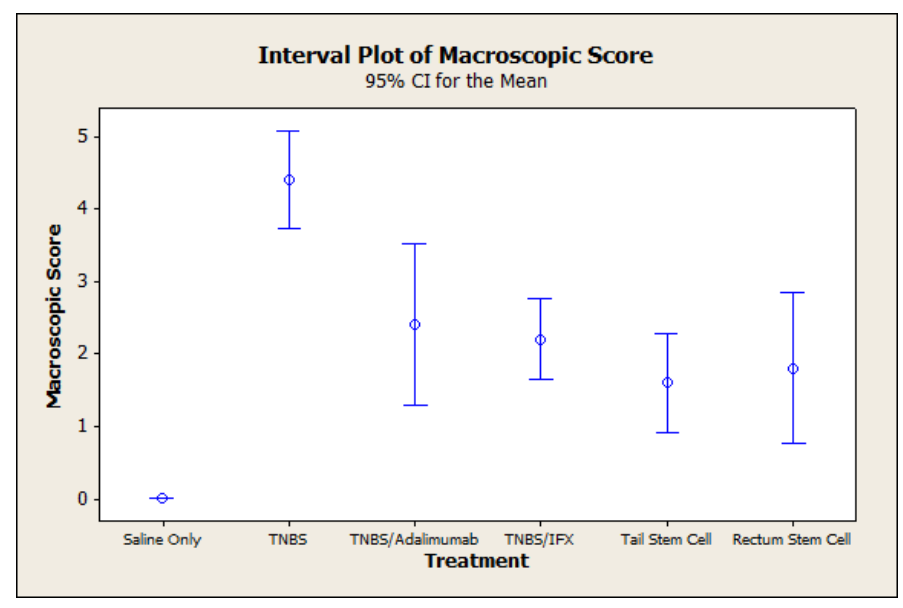

Figure 4. Colonic macroscopic score on day 4 after the induction of TNBS colitis $(\mathrm{p}<0.001)$.

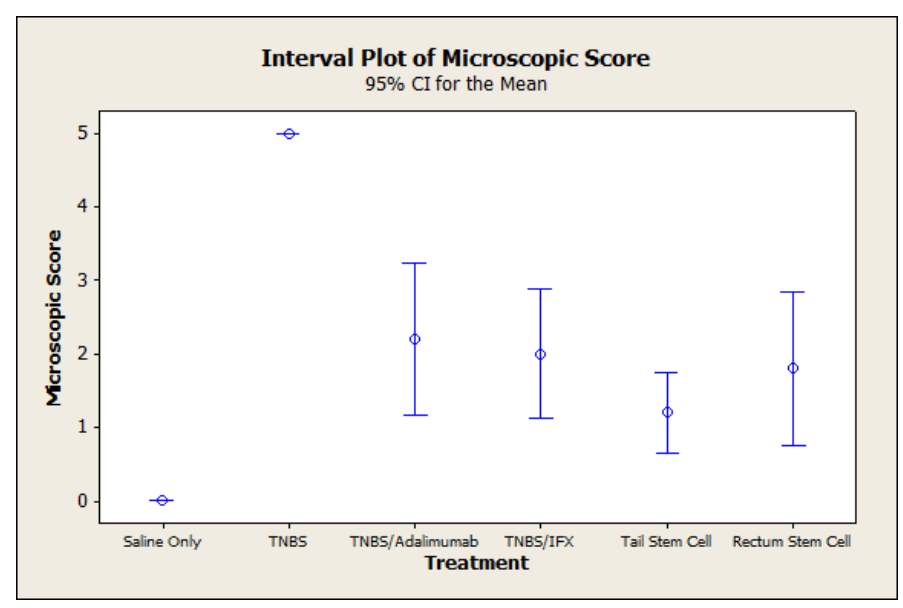

Figure 5. Colonic microscopic score on day 4 after the induction of TNBS colitis.

Traditionally, drug treatments of inflammatory diseases primarily aim to repair tissue damage caused by the inhibition of cytokines, especially TNF-alpha. In addition to these, polypharmacy has sustained a high level of failure in treatment with frequently observed side effects [19].

This study identifies new therapeutic paths using mesenchymal stem cells in Wistar, to minimize the side effects of intravenous cell therapy, and to compare the effectiveness of these therapies with that of biological therapies [12].

This research demonstrates the effectiveness of TNBS in producing tissue damage when compared to which was not ably marked when compared with the normal group (saline solution), in which sick animals experienced significant weight loss and significantly increased serum IL6 and TNF-alpha levels (Figures 1-3). Macroscopically and microscopically, high scores were demonstrated in the sick groups compared with the untreated animals $(\mathrm{p}<0.001)$ (Figures 4 and 5, respectively).

Conversely, weight began to be restored when the animals were subjected to treatment with biological agents, a difference that was more evident in animals treated with Infliximab followed by Adalimumab $(\mathrm{p}<0.001)$. Clinically, animals treated with Adalimumab tended to take longer to restore their weight than those treated with Infliximab $(\mathrm{p}<0.05)$, which might be due to the fact that Adalimumab is a humanized biological agent and Infliximab is a chimera that would have greater specificity to murine TNF-alpha. In the group under cell therapy, the weight began to be restored for both rectal and intravenous applications,compared with the TNBS group; greater differences were particularly observed on the third day $(\mathrm{p}<0.001)$.

In general, the serum inflammatory parameters (TNF-alpha and IL6) in groups treated with biological agents or stem cells (intravenous or topical) were lower, compared with the sick group. No significant difference was detected in the intergroup analysis (biological groups) $(\mathrm{p}<0.05)$, which demonstrates that both treatments are effective for blocking cytokines. When anti-TNF and cell therapy agents were compared, anti-TNF proved to be more powerful than stem cells $(\mathrm{p}<0.01)$.

Macroscopically and microscopically, all treated animals exhibited better scores, compared with the sick groups (Figures 4 and 5). No differences were observed between the anti-TNF agents $(\mathrm{p}<0.995$ and $\mathrm{p}<0.994$, respectively), and both were similarly effective for healing the mucosa.

Histological and macroscopic recoveries were also observed with stem cells, with no difference between the two treatments $(\mathrm{p}<0.995$ and $\mathrm{p}<0.604$, respectively). Thus, we observed that, even when applied via enema, the stem cells had a therapeutic effect.

Previous studies have indicated that the cell response is initially interpreted by the migration of these cells to the target location and by the differentiation of these cells in target tissues. This fact explains why, when administering the treatment in the colon via enema, the cell response was sufficient [1]. Hez et al. demonstrated the capacity of mesenchymal cells to inhibit both IL6 and TNF-alpha and to induce histological repair, with similar results compared with those demonstrated here [1].

Physiologically, these effects appear to be directly associated with paracrine signals, which favor the migration of stem cells to the lesion site, regardless of its location. Another hypothesis is based on cell-tocell contact combined with the multiplication of cells similar to their matrix, with the modulation properties of the inflammatory immune response and the release of cytokine inhibitors and reactive oxygen species (NO) acting with scanning effects on the inflammatory cascade [20]. Other studies also report a preventive action of cell therapy in the presence of TNBS damage [7].

Recently, Stavely et col. showed that in animal models of colitis (guinea pig bone marrow MSCs) the mesenchymal stem cell is able to imunomodulate the inflammatory response due to its capacity of effective penetration and leukocyte infiltration into the mucosa and myenteric plexus and sources secreted TGF- $\beta 1$ [21,22]. Thus, the combination of these factors have demonstrated themselves to be one of the mechanisms via which experimental colitis caused by TNBS can be attenuated [22].

Experiments with enema of mesenchymal stem cells have been applied in guinea-pigs demonstrating the effectiveness of these cells in the treatment of neuropathy and plexitis. As well as MSCs derived from adipose tissue [23,24].

Knowingly, studies in guinea-pigs seem to more effectively simulate Inflammatory Disease as it happens in humans when compared to experimental models in Wistar rats. However, both studies can reinforce new pathways to the applicability of these cells by enema [25].

We used the cell therapy only when the damage had already been 
established, but recent studies have demonstrated that these cells could prevent tissue damage [26-29].

\section{Conclusion}

This study suggests new methods for treating inflammatory bowel disease in relation to the use of topical and intravenous applications of stem cells. Although we have had better results via intravenous, we believe that in the future stem cell applications via enema can present an alternative with less side effects. The assessment of clinical parameters, microscopic and macroscopic scores and chemical mediators of inflammation (including IL-6 and TNF-alpha) all support these conclusions. Additional studies should be conducted to obtain further evidence of these associations.

\section{Acknowledgements}

Alan Moss MD, BIDMC, Harvard/Boston.

\section{References}

1. He Z, Hua J, Song Z (2014) Concise Review: Mesenchymal Stem Cells Ameliorate Tissue Injury via Secretion of Tumor Necrosis Factor-ÎI Stimulated Protein/Gene 6 . Stem Cells Int 2014: 761091. [Crossref]

2. Lee D, Albenberg L, Compher C, Baldassano R, Piccoli D, et al. (2015) Diet in the pathogenesis and treatment of inflammatory bowel diseases. Gastroenterology 148: 1087-1106. [Crossref]

3. Cammarota G, Ianiro G, Cianci R, Bibbò S, Gasbarrini A, et al. (2015) The involvement of gut microbiota in inflammatory bowel disease pathogenesis: potential for therapy. Pharmacol Ther 149: 191-212. [Crossref]

4. Ellinghaus D, Bethune J, Petersen BS, Franke A (2015) The genetics of Crohn's disease and ulcerative colitis--status quo and beyond. Scand J Gastroenterol 50: 1323. [Crossref]

5. Danese S, Peyrin-Biroulet L (2014) Editorial. Medical challanges in inflammatory bowel disease: quo vadis in disease complexity? Curr Drug Targets 15: 1001. [Crossref]

6. Ben-Horin S, Kopylov U, Chowers Y (2014) Optimizing anti-TNF treatments in inflammatory bowel disease. Autoimmun Rev 13: 24-30. [Crossref]

7. Robinson AM, Sakkal S, Park A, Jovanovska V, Payne N, et al. (2014) Mesenchymal stem cells and conditioned medium avert enteric neuropathy and colon dysfunction in guinea pig TNBS-induced colitis. Am J Physiol Gastrointest Liver Physiol 307: G11151129. [Crossref]

8. Theede K, Dahlerup JF, Fallingborg J, Hvas CL, Kjeldsen J, et al. (2013) Biologic therapy in inflammatory bowel disease. Dan Med J 60: B4652. [Crossref]

9. Gazouli M, Roubelakis MG, Theodoropoulos GE (2014) Stem cells as potential targeted therapy for inflammatory bowel disease. Inflamm Bowel Dis 20: 952-955. [Crossref]

10. Nagaishi K, Arimura Y, Fujimiya M (2015) Stem cell therapy for inflammatory bowel disease. $J$ Gastroenterol 50: 280-286. [Crossref]

11. Abdel Salam AG, Ata HM, Salman TM3, Rashed LA, Sabry D, et al. (2014) Potential therapeutic utility of mesenchymal stem cells in inflammatory bowel disease in mice. Int Immunopharmacol 22: 515-521. [Crossref]

12. Peinemann F, van Dalen EC, Tushabe DA, Berthold F (2015) Retinoic acid pos consolidation therapy for high-risk neuroblastoma patients treated with autologous hematopoietic stem cell transplantation. Cochrane Database Syst Rev 1: CD010685. [Crossref]
13. Martino R, Bautista G, Parody R, García I, Esquirol A,et al. Severe infections after single umbilical cord blood transplantation in adults with or without the co-infusion of CD34 cells from a third-party donor: results of a multicenter study from the Grupo Espanol de Trasplante Hematopoyetico (GETH). Transpl Infect Dis 17: 221-233. [Crossref]

14. Maiese K (2015) MicroRNAs and SIRT1: A Strategy for Stem Cell Renewal and Clinical Development? J Transl Sci 1: 55-57. [Crossref]

15. Morris GP, Beck PL, Herridge MS, Depew WT, Szewczuk MR, et al. (1989) Hapteninduced model of chronic inflammation and ulceration in the rat colon. Gastroenterology 96: 795-803. [Crossref]

16. Ando Y, Inaba M, Sakaguchi Y, Tsuda M, Quan GK, et al. (2008) Subcutaneous adipose tissue-derived stem cells facilitate colonic mucosal recovery from ,4,6-trinitrobenzene sulfonic acid (TNBS)-induced colitis in rats. Inflamm Bowel Dis 14: 826-838. [Crossref]

17. Reis LA, Borges FT, Simoes MJ, Borges AA, Sinigaglia-Coimbra R, et al. (2012) Bone marrow-derived mesenchymal stem cells repaired but did not prevent gentamicininduced acute kidney injury through paracrine effects in rats. PLoS One 7: e44092. [Crossref]

18. Cury DB, Mizsputen SJ, Versolato C, Miiji LO, Pereira E, et al. (2013) Serum calprotectin levels correlate with biochemical and histological markers of disease activity in TNBS colitis. Cell Immunol 282: 66-70. [Crossref]

19. Gisbert JP, Marin AC, McNicholl AG, Chaparro M (2015) Systematic review with meta-analysis: the efficacy of a second anti-TNF in patients with inflammatory bowel disease whose previous anti-TNF treatment has failed. Aliment Pharmacol Ther 41: 613-623. [Crossref]

20. Pittenger M (2009) Sleuthing the source of regeneration by MSCs. Cell Stem Cell 5 : 8-10. [Crossref]

21. Stavely R, Robinson AM, Miller S, Boyd R, Sakkal S, et al. (2015) Allogeneic guinea pig mesenchymal stem cells ameliorate neurological changes in experimental colitis. Stem Cell Res Ther 6: 263. [Crossref]

22. Stavely R, Robinson AM, Miller S3, Boyd R4, Sakkal S5, et al. (2015) Human adult stem cells derived from adipose tissue and bone marrow attenuate enteric neuropathy in the guinea-pig model of acute colitis. Stem Cell Res Ther 6: 244. [Crossref]

23. Robinson AM, Miller S, Payne N, Boyd R3, Sakkal S, et al. (2015) Neuroprotective Potential of Mesenchymal Stem Cell-Based Therapy in Acute Stages of TNBS-Induced Colitis in Guinea-Pigs. PLoS One 10: e0139023. [Crossref]

24. Forte D, Ciciarello M, Valerii MC, De Fazio L, Cavazza E, et al. Human cord blood-derived platelet lysate enhances the therapeutic activity of adipose-derived mesenchymal stromal cells isolated from Crohn's disease patients in a mouse model of colitis. Stem Cell Res Ther 6: 170. [Crossref]

25. Kiesler P, Fuss IJ, Strober W (2015) Experimental Models of Inflammatory Bowel Diseases. Cell Mol Gastroenterol Hepatol 1: 154-170. [Crossref]

26. Hayashi Y, Tsuji S, Tsujii M, Nishida T, Ishii S, et al. (2008) Topical implantation of mesenchymal stem cells has beneficial effects on healing of experimental colitis in rats. J Pharmacol Exp Ther 326: 523-531. [Crossref]

27. Kriván G, Szabó D, Kállay K, Benyó G, Kassa C, et al. (2014) Successful autologous haematopoietic stem cell transplantation in severe, therapy-resistant childhood Crohn's disease. Report on the first case in Hungary. Orv Hetil 155: 789-792. [Crossref]

28. Martínez-Montiel Mdel P, Gómez-Gómez GJ, Flores AI (2014) Therapy with stem cells in inflammatory bowel disease. World J Gastroenterol 20: 1211-1227. [Crossref]

29. Knyazev OV, Parfenov AI, Shcherbakov PL, Ruchkina IN, Konoplyannikov AG (2013) Cell therapy of refractory Crohn's disease. Bull Exp Biol Med 156: 139-145. [Crossref]

Copyright: (C2015 Safdar OY. This is an open-access article distributed under the terms of the Creative Commons Attribution License, which permits unrestricted use, distribution, and reproduction in any medium, provided the original author and source are credited. 